\title{
DNA Repair Protein RAD52 Homolog
}

National Cancer Institute

\section{Source}

National Cancer Institute. DNA Repair Protein RAD52 Homolog. NCI Thesaurus. Code C106265.

DNA repair protein RAD52 homolog (418 aa, $46 \mathrm{kDa}$ ) is encoded by the human RAD52 gene. This protein is involved in both homologous recombination and double-strand break repair. 